\title{
GAMBARAN ADVERSITY QUOTIENT PADA SISWA DI SMU NEGERI 27 JAKARTA PUSAT
}

\author{
Sri Maryani \\ Jurusan Psikologi Pendidikan, Fakultas Ilmu Pendidikan, Universitas Negeri jakarta \\ Jalan Rawamangun Muka Jakarta Timur 13220, DKI Jakarta \\ E-mail: srie.maryani91@yahoo.com
}

\begin{abstract}
The aim of this research is to determine description adversity quotient of student at SMUN 27 Jakarta Pusat. This research took place at SMUN 27 Jakarta Pusat started from May to July 2011. This research use descriptive quantitive method. The population of this research are 2nd grade student of SMUN 27 Jakarta. 100 student are choosen as research sample with accidental sampling. Research instrument used is questionnaire with likert model scaling. Data analysiss technique used is frequent and percentage using SPSS for windows (version 16). Adversity response profile develop by Paul G. Stoltz Used as data collection method. The result showed that 12 respondent $(12 \%)$ of total 100 are in high category (Climbers), 87 respondent $(87 \%)$ in middle category (Campers) and 1 respondent (1\%) in low category (Quitters).
\end{abstract}

Key words : Adversity Quotient, Student

\section{Pendahuluan}

Pendidikan adalah suatu usaha atau kegiatan yang dijalankan dengan sengaja, teratur dan berencana dengan maksud mengubah atau mengembangkan perilaku yang diinginkan. Sekolah sebagai lembaga formal merupakan sarana dalam rangka pencapaian tujuan pendidikan tersebut. Proses belajar yang terjadi pada individu memang merupakan sesuatu yang penting, karena melalui belajar individu mengenal lingkungannya dan menyesuaikan diri dengan lingkungan di sekitarnya. Menurut Morgan dalam bukunya "Introduction to Psychology" dikemukakan bahwa: "Belajar adalah setiap perubahan yang relatif menetap dalam tingkah laku yang terjadi sebagai suatu hasil dari latihan atau pengalaman (WordPres: 2011). Belajar akan menghasilkan perubahan - perubahan dalam diri seseorang. Penilaian terhadap hasil belajar seorang siswa untuk mengetahui sejauh mana telah mencapai sasaran belajar inilah yang disebut sebagai prestasi belajar. Prestasi belajar menurut Ghandi Wirawan adalah: "Hasil yang dicapai seorang siswa dalam usaha belajarnya sebagaimana dicantumkan di dalam nilai rapornya. Melalui prestasi belajar seorang siswa dapat mengetahui kemajuan - kemajuan yang telah dicapainya dalam belajar (Majalah Pendidikan: 2011).

Suatu hal yang wajar, sekolah pada umumnya selalu berupaya bagaimana sekolah tersebut memiliki Sumber Daya Manusia yang mampu menampilkan prestasi yang baik. Padahal prestasi seseorang dipengaruhi oleh berbagai hal, antara lain kemampuan kognitif, kemampuan teknis, kecerdasan emosional dan kecerdasan spiritual.

Namun dalam upaya meraih prestasi belajar yang memuaskan dibutuhkan proses belajar. Proses belajar yang terjadi pada siswa memang merupakan sesuatu yang penting, karena melalui belajar siswa mengenal lingkungannya dan menyesuaikan diri dengan lingkungan di sekitarnya.

Setiap siswa dalam proses belajarnya pasti mengalami berbagai hambatan atau permasalahan, begitupun dengan siswa-siswa di SMU Negeri 27 Jakarta. Mereka harus mengahadapi tantangantantangan dan permasalahan, baik permasalahan bidang akademik maupun dalam hidupnya, akan tetapi banyak diantara 
mereka yang berprestasi dan tetap bersekolah. Hal ini berarti ada suatu hal yang membuat siswa itu bertahan diantara kesulitan dan tantangan hidup yang dihadapi.

Adversity Quotient (AQ) adalah respon seseorang berupa kemampuan dan ketahanan dalam menghadapi kesulitan, kegagalan, hambatan, atau tantangan hidup, sekaligus mengubah kesulitan maupun kegagalan tersebut menjadi peluang atau batu loncatan.

Adversity Quotient (AQ) mengukur kemampuan seseorang dalam menghadapi kesulitan ( Paul G. Stoltz: 2005: 9). Adversity Quotient merupakan bentuk kecerdasan yang melatar belakangi kesuksesan seseorang, dimana orang Berdasarkan penjelasan di atas, maka penulis ingin mengadakan penelitian untuk mengetahui gambaran Adversity Quotent pada Siswa di SMU Negeri 27 Jakarta Pusat.

\section{Pengertian Adversity Quotient}

Adversity memiliki makna usaha untuk tegar atau berjuang untuk keluar dari segala kekurangbaikkan (Kamus Besar Indonesia: 2007). Roosseno mendefinisikan AQ sebagai kemampuan atau kecerdasan ketangguhan berupa seberapa baik individu bertahan atas cobaan yang dialami dan seberapa baik kemampuan individu untuk mengatasinya (Wiratman Wangsadinata: 2008: 263). Dapat disimpulkan Adversity merupakan kecerdasan individu untuk berjuang dan bertahan hidup dalam menghadapi cobaan hidup yang dialaminya serta bagaimana cara mengatasinya.

Adversity Quotient (AQ) dikembangkan pertama kali oleh Paul G. Stoltz. Seorang konsultan yang sangat terkenal dalam topik - topik kepemimpinan di dunia kerja dan dunia pendidikan berbasis skill, Ia menganggap bahwa IQ dan EQ yang sedang marak dibicarakan itu tidaklah cukup dalam meramalkan kesuksesan seseorang. Stoltz mengelompokkan individu menjadi tiga: quitter, camper, dan climber.

Kecerdasan adversitas (AQ (Adversity Quotient)) adalah kecerdasan yang dimiliki seseorang dalam mengatasi kesulitan dan sanggup bertahan hidup. Dengan AQ seseorang bagai diukur kemampuannya dalam mengatasi setiap persoalan hidup untuk tidak berputus asa (Sulaiman $\mathrm{Al}$ Kumayi: 2006: 118). Dalam kamus bahasa Inggris, kata "Adversity" di artikan dengan kesengsaraan dan kemalangan, sedangkan "Intelegence" diartikan dengan kecerdasan (Kamus Inggris Indonesia: 14). Dalam buku Properthic Intelegence, di sebutkan Adversity Quotient, merupakan sesuatu potensi di mana dengan potensi ini seseorang dapat mengubah hambatan menjadi peluang lalu Ia menyatakan bahwa suksesnya suatu pekerjaan dan hidup seseorang di tentukan oleh Adversity Quotient (AQ) (Barkan Adz Dzakiey: 2005: 605). Analisa Stoltz yang memiliki $A Q$, mereka tidak mudah menyerah dan mempunyai semangat tinggi untuk mencapai tujuan

Berdasarkan wawancara dengan Bapak Eling Budiharso selaku wakil kepala sekolah bidang kesiswaan di SMU Negeri 27 Jakarta Pusat didapat fenomena bahwa para siswa di sekolah ini memiliki potensi untuk mencapai nilai atau prestasi akademik yang lebih baik lagi, tetapi menurut beliau daya juang (AQ) mereka begitu rendah sehingga tidak didapatkan hasil yang maksimal. Dalam buku Adversity Quotient terdapat beberapa penelitian yang menyangkut perbedaan siswa dalam menghadapi masalahnya.

AQ (Adversity Quotient) menggambarkan pola seseorang mengolah tanggapan atas semua bentuk dan intensitas kesulitan, serta tragedi besar hingga gangguan sepele (Paul G. Stoltz: 2005: 8). Konsep baru ini menawarkan manfaat yang dapat diperoleh, yaitu:

1. AQ menyatakan seberapa tegar seseorang menghadapi kemalangan dan menerima sebuah tantangan

2. AQ memperkirakan siapa yang mampu mengatasi kemalangan tersebut dan siapa yang akan terlibas.

3. AQ dapat memperkirakan siapa yang dapat melampaui harapan kinerja dan potensinya dan siapa yang tidak.

4. AQ memperkirakan siapa yamg berputus asa dan siapa yang bertahan.

5. AQ mewujudkan dua komponen essensial yang amat praktis yaitu teori Ilmiah dan aplikasi nyata, karena AQ terwujud dalam tiga bentuk yaitu:

a. Keberhasilan konseptual baru untuk memahami dan meningkatkan semua aspek keberhasilan.

b. Merupakan ukuran bagaimana seseorang merespon kemalangan.

c. Merupakan alat untuk memperbaiki respon seseorang terhadap kemalangan.

Dengan demikian AQ mampu memprediksi seseorang atau individu pada tampilan motivasi, pemberdayaan, kreativitas, produktivitas, pembelajaran, energi, harapan, kegembiraan, vitalitas dan kesenangan, kesehatan mental, kesehatan jasmani, daya tahan, fleksibilitas, perbaikan sikap, daya hidup dan respon terhadap perubahan terutama dalam hal ini adalah siswa yang mempunyai kelebihan khusus, baik intelegensi, kreatifitas, ataupun skill dan potensi lebih. 


\section{Tipe - tipe Adversity Quotient}

Stoltz, dengan konsep AQ begitu meyakinkan dan membagi manusia dalam tiga kelompok (Paul G. Stoltz: 2005: 8). sebagai berikut:

1. Quitters, (mereka yang berhenti). yaitu orang yang berhenti ditengah pendakian, gampang putus asa, dan mudah menyerah, mudah puas dengan pemuas kebutuhan dasar fisiologis saja, cenderung pasif, tidak bergairah untuk mencaai puncak keberhasilan.

2. Campers, (pekemah). Tidak mencapai puncak, sudah puas dengan apa yang dicapai, orang seperti ini yang sedikit lebih baik dari quitters, yaitu masih mengusahakan terpenuhinya kebutuhan rasa aman dan keamanan dan kebersamaan, serta masih bisa melihat dan merasakan tantangan pada skala hirarki Maslow.

3. Climbers, (pendaki) yaitu orang yang selalu berupaya mencapai puncak pendakian yaitu kebutuhan aktualisasi diri pada skala kebutuhan Maslow, siap menghadapi berbagai rintangan.

Campers mungkin tidak menggunakan seluruh kemampuannya.

\section{Dimensi - dimensi Adversity Quotient}

Stoltz menyebutkan empat dimensi yang menyusun Adversity Quotient seseorang, empat dimensi tersebut dijelaskan sebagai berikut :

1. Kendali diri (Control) atau kendali, kemampuan individu dalam mempengaruhi secara positif suatu situasi, serta mampu mengendalikan respon terhadap situasi, dengan pemahaman awal bahwa sesuatu apapun dalam situasi apapun individu dapat melakukannya dimensi ini memiliki dua fase yaitu pertama, sejauh mana seseorang mampu mempengaruhi secara positif suatu situasi? Kedua, yaitu sejauh mana seseorang mampu mengendalikan respon terhadap suatu situasi.

2. Asal - usul dan pengakuan (Origin dan Ownership), yaitu suatu kemampuan individu dalam menempatkan perasaan dirinya dengan berani menaggung akibat dari situasi yang ada, sehingga menciptakan pembelajaran dalam melakukan perbaikan atas masalah yang terjadi.

3. Jangkauan (Reach), kemampuan individu dalam menjangkau dan membatasi masalah agar tidak menjangkau bidang - bidang yang lain dimensi ini melihat sejauh mana individu membiarkan kemalangan menjangkau bidang lain pekerjaan dan hidup individu.

4. Daya tahan (Endurance), yaitu kemampuan individu dalam mempersepsi kesulitan, dan kekuatan dalam menghadapi kesulitan tersebut dengan menciptakan ide dalam pengatasan masalah sehingga ketegaran hati dan keberanian dalam penyeleasaian masalah dapat terwujud dimensi ini berupaya melihat berapa lama seseorang mempersepsi kemalangan ini akan berlangsung.

\section{Peran Adversity Quotient dalam Kehidupan}

Stoltz mengindikasikan bahwa Adversity Quotient mempunyai kontribusi yang sangat besar karena faktor - faktor kesuksesan yang tertulis dan memilki dasar ilmiah ini dipengaruhi, kalau bukan ditentukan, oleh kemampuan pengendalian serta cara kita merespon kesulitan, faktor - faktor tersebut mencakup semua yang diperlukan untuk meraih tantangan (Paul G. Stoltz: 2005: 93). Faktor tersebut antara lain:

1. Daya saing, menurut penelitian Jasson Stterfield dan Martin Seligman, terhadap retorika Saddan Hussen dan Josh Bush, menemukan bahwa orang - orang yang merespon kesulitan secara lebih optimis, bisa diramalkan akan bisa bersikap lebih agresif dan mengambil lebih banyak resiko, sedangkan reaksi yang lebih pesimis terhadap kesulitan menimbulkan lebih banyak sikap pasif dan berhati - hati.

2. Produktifitas, Selligman membuktikan bahwa orang yang tidak merespon kesulitan dengan baik menjual lebih sedikit, kurang berproduksi, dan kinerjanya lebih buruk daripada mereka yang merespon kesulitan dengan baik

3. Kreativitas, Inovasi pada pokonya merupakan tindakan berdasarkan suatu harapan. Inovasi membutuhkan keyakinan bahwa sesuatu yang sebelumnya tidak ada dapat menjadi ada.

4. Motivasi, dalam sebuah perusahaan farmasi seorang direktur mengurutkan timnya sesuai dengan motivasi mereka yang terlihat. Kemudian mengukur AQ, anggota timnya. tanpa kecuali, baik berdasarkan pekerjaan harian maupun untuk jangka panjang, mereka yang AQnya tinggi dianggap sebagai orang -orang yang paling memilki motivasi.

5. Mengambil Resiko, Orang - orang yang merespon kesulitan secara lebih konstruktif bersedia mengambil lebih banyak resiko.

6. Perbaikan, perbaikan sangat diperlukan dalam upaya mempertahankan hidup

7. Ketekunan, ketekunan adalah inti dari AQ, yaitu sebuah kemampuan untuk terus menerus berusaha, bahkan ketika dihadapkan pada kemunduran kemunduran atau kegagalan 
8. Belajar, menurut penelitian yang di lakukan oleh Carol Dweck membuktikan bahwa anak - anak dengan respon pesimistis terhadap kesulitan tidak akan banyak belajar dan berpestasi jka di bandingkan dengan anak - anak yang memilki pola - pola yang lebih optimistis.

9. Merangkul Perubahan, individu yang memeluk perubahan cenderung merespon kesulitan secara lebih konstruktif dengan memanfaatkanya untuk memperkuat niat mereka.

10. Keuletan, Stres, Tekanan, Kemunduruan, Suzanne Oulette, peneliti terkemuka untuk sifat tahan banting, memperlihatkan bahwa orang - orang yang merspon kesulitan dengan sifat tahan banting pengendalian, tantangan dan komitmen, akan tetap ulet dalam menghadapai kesulitan - kesulitan.

\section{Metode Penelitian}

Metode penelitian yang digunakan dalam penelitian ini adalah penelitian deskriptif kuantitatif, yaitu menggambarkan masalah yang akan diteliti, dan data yang diperoleh berbentuk angka yang akan dianalisis memakai analisis statistik (Nida'u Diana: 2008: 63). Tujuan dari penelitian deskriptif adalah menghasilkan gambaran akurat tentang sebuah kelompok, menggambarkan mekanisme sebuah proses atau hubungan, memberikan gambaran lengkap baik dalam bentuk verbal atau numerikal, menyajikan informasi dasar akan suatu hubungan, menciptakan seperangkat kategori dan mengklasifikasikan subjek penelitian, menjelaskan seperangkat tahapan atau proses, serta untuk menyimpan informasi bersifat kontradiktif mengenai subjek penelitian (Wikipedia: 2011). Dalam hal ini yang diteliti adalah gambaran Adversity Quotient siswa SMU Negeri 27 Jakarta Pusat.

\section{Hasil \& Diskusi}

Berikut ini adalah hasil \& diskusi dari penelitian mengenai gambaran Adversity Quotient pada siswa di SMU Negeri 27 Jakarta Pusat yang dilakukan pada bulan juli 2011 :

\section{Tabel Komposisi Subjek Berdasarkan Jenis} Kelamin

\begin{tabular}{ccc}
\hline $\begin{array}{c}\text { Jenis } \\
\text { Kelamin }\end{array}$ & Frekuensi & Persentase \\
\hline Laki-laki & 42 & $42 \%$ \\
Perempuan & 58 & $58 \%$ \\
Total & 100 & $100 \%$ \\
\hline
\end{tabular}

Berdasarkan tabel di atas dapat diketahui bahwa jumlah responden laki - laki 42 orang dengan persentase sebesar $42 \%$ dan jumlah responden perempuan 58 orang dengan persentase sebesar $58 \%$

Berikut ini adalah gambaran jumlah subjek berdasarkan usia. Untuk lebih jelasnya lihat tabel

\section{Tabel Komposisi Subjek Berdasarkan Usia}

\begin{tabular}{ccc}
\hline Usia & Frekuensi & Persentase \\
\hline $\mathbf{1 5}$ tahun & 17 & $17 \%$ \\
$\mathbf{1 6}$ tahun & 52 & $52 \%$ \\
$\mathbf{1 7}$ tahun & 29 & $29 \%$ \\
$\mathbf{1 8}$ tahun & 2 & $2 \%$ \\
Total & 100 & $100 \%$ \\
\hline
\end{tabular}

Berdasarkan tabel di atas dapat diketahui bahwa jumlah responden berusia 15 tahun sebanyak 17 orang, usia 16 tahun sebanyak 59, usia 17 tahun sebanyak 29, dan usia 18 tahun sebanyak 2 orang. Responden terbanyak berusia 16 tahun dan yang paling sedikit berusia 18 tahun.

\section{Uji Normalitas}

Uji kenormalan bertujuan untuk menguji bahwa data sampel berasal dari populasi yang terdistribusi secara normal. Penghitungan uji normalitas dalam penelitian ini menggunakan Saphiro-Wilk karena jumlah responden pengujian kurang dari atau sama dengan 100 (Kuncono: 2004). Data terdistribusi normal apabila signifikasi Saphiro-Wilk $>$ taraf signifikasi $(\alpha=0,05)$. Berikut ini adalah hasil penghitungan menggunakan SPSS versi 16.

Tabel Hasil Penghitungan Uji Normalitas

\begin{tabular}{|c|c|c|c|}
\hline \multirow[b]{2}{*}{$\begin{array}{l}\text { Variabe } \\
\text { l }\end{array}$} & \multicolumn{3}{|c|}{ Shapiro-Wilk } \\
\hline & $\begin{array}{c}\text { Shapiro Wilk } \\
\text { (p) }\end{array}$ & Sig & Interpretasi \\
\hline $\begin{array}{l}\text { Adversit } \\
y \\
\text { Quotient }\end{array}$ & 961 & 0,005 & Normal \\
\hline
\end{tabular}

Dari data di atas dapat disimpulkan bahwa data variabel Adversity Quotient berdistribusi normal.

\section{Gambaran Data Variabel Adversity Quotient}

Distribusi data merupakan gambaran penyebaran atau distribusi dari sekelompok data yang diobservasi (Kuncono: 2004). Data tersebut berdistribusi normal. Dari hasil perhitungan dengan memakai SPSS versi 16, maka didapat data sebagai berikut : 
Tabel Gambaran Data Variabel Adversity Quotient

\begin{tabular}{lr}
\hline \multicolumn{2}{c}{ Pemusatan dan Penyebaran data } \\
\hline N & 100 \\
Mean & 82,11 \\
Median & 82,50 \\
Mode & 82,50 \\
Std.Deviation & 6,739 \\
Minimum & 58 \\
Maximum & 103 \\
Range & 45 \\
\hline
\end{tabular}

Dari tabel di atas dapat dilihat bahwa rata-rata data variabel Adversity Quotient sebesar 82,11, nilai median 75, 50 , nilai modus 82 , skor minimum yang diperoleh subjek sebesar 58 dan skor maksimum sebesar 103 .

\section{Distribusi Pengkategorian Skor}

Kategori skor dilakukan untuk menempatkan responden ke dalam kategori kategori atau kelompok - kelompok yang berjenjang apabila skor kelompok responden terdistribusi normal. Pemisahan skor dibagi ke dalam kelompok tinggi, sedang dan rendah (Kuncono : 2004: 35).

Individu yang berada pada kategori tinggi diasumsikan sebagai climber, yang berada pada kategori sedang adalah campers dan yang berada pada kategori rendah adalah quitters.

Tabel Kategorisasi Skor Variabel Adversity Quotient mana yang menonjol pada responden dalam menghadapi kesulitan. Kategorisasi skor per dimensi didapatkan berdasarkan rumus yang sama dengan kategorisasi skor AQ.

Tabel Kategorisasi Skor Control

\begin{tabular}{|c|c|c|c|c|}
\hline No & Skor & Keterangan & Jumlah & Persentase \\
\hline 1 & $X>24$ & Tinggi & 40 & $40 \%$ \\
\hline 2 & $24 \geq X \geq 16$ & Sedang & 58 & $58 \%$ \\
\hline 3 & $X<16$ & Rendah & 2 & $2 \%$ \\
\hline & \multicolumn{2}{|c|}{ Jumlah } & 100 & $100 \%$ \\
\hline
\end{tabular}

Dari tabel diatas dapat diketahui bahwa responden yang skor control-nya berada dalam kategori tinggi sebanyak 40 orang $(40 \%)$, kategori sedang 58 orang $(58 \%)$, dan yang berada dalam kategori rendah sebanyak 2 orang $(2 \%)$

Tabel Kategorisasi skor O2 (Origin dan Ownership)

\begin{tabular}{ccccc}
\hline No & Skor & Keterangan & Jumlah & Persentase \\
\hline $\mathbf{1}$ & $\mathrm{X}>15,17$ & Tinggi & 55 & $55 \%$ \\
$\mathbf{2}$ & $15,17 \geq \mathrm{X} \geq 9,83$ & Sedang & 45 & $45 \%$ \\
$\mathbf{3}$ & $\mathrm{X}<9,83$ & Rendah & 0 & $0 \%$ \\
& Jumlah & & 100 & $100 \%$ \\
\hline
\end{tabular}

Dapat diketahui bahwa responden yang skor Origin and Ownership-nya berada dalam kategori tinggi sebanyak 55 orang (55\%), kategori sedang 45 orang $(45 \%)$, dan yang berada dalam kategori rendah tidak ada.

\begin{tabular}{ccccc}
\hline No & Skor & Keterangan & Jumlah & Persentase \\
\hline $\mathbf{1}$ & $X>21$ & Tinggi & 65 & $65 \%$ \\
$\mathbf{2}$ & $21 \geq X \geq 14$ & Sedang & 35 & $35 \%$ \\
$\mathbf{3}$ & $\mathrm{X}<14$ & Rendah & 0 & $0 \%$ \\
\multicolumn{2}{r}{ Jumlah } & & 100 & $100 \%$ \\
\hline
\end{tabular}

\begin{tabular}{ccccc}
\hline No & Skor & Keterangan & Jumlah & Persenta \\
\hline $\mathbf{1}$ & $\mathrm{X}>90$ & Tinggi & 12 & $12 \%$ \\
$\mathbf{2}$ & $90 \geq \mathrm{X} \geq 60$ & Sedang & 87 & $87 \%$ \\
$\mathbf{3}$ & $\mathrm{X}<60$ & Rendah & 1 & $1 \%$ \\
\multicolumn{2}{c}{ Jumlah } & 100 & $100 \%$ \\
\hline
\end{tabular}

Tabel Kategorisasi Skor Reach

$87 \%$

$100 \%$ Dari dapat diketahui bahwa responden yang skor reach-nya berada dalam kategori tinggi tidak ada, kategori sedang 65 orang (65\%), dan yang berada dalam kategori rendah sebanyak 35 orang $(35 \%)$. subjek dapat dikelompokkan ke dalam tiga jenjang, yaitu ada 12 orang (12\%) subjek yang berada pada kategori tinggi atau climbers, 87 orang (87\%) subjek pada kategori sedang atau campers, dan 1 orang $(1 \%)$ subjek berada pada kategori rendah atau quitters.

\section{Distribusi Pengkategorian Skor Berdasarkan Dimensi}

Kategori skor berdasarkan dimensi pada instrumen bertujuan untuk mengetahui dimensi

\begin{tabular}{ccccc}
\hline No & Skor & Keterangan & Jumlah & Persentase \\
\hline $\mathbf{1}$ & $\mathrm{X}>36$ & Tinggi & 0 & $0 \%$ \\
$\mathbf{2}$ & $36 \geq X \geq 24$ & Sedang & 40 & $40 \%$ \\
$\mathbf{3}$ & $\mathrm{X}<24$ & Rendah & 60 & $60 \%$ \\
\multicolumn{2}{c}{ Jumlah } & 100 & $100 \%$ \\
\hline
\end{tabular}

Tabel Kategorisasi Skor Endurance 
Berdasarkan hasil pengumpulan dan penghitungan data statistika yang telah dilakukan, dari 100 responden, terdapat 12 orang (12\%) subjek yang berada pada kategori tinggi atau climbers, 87 orang $(87 \%)$ orang subjek pada kategori sedang atau campers, dan 1 orang (1\%) subjek berada pada kategori rendah atau quitters. Hal tersebut berarti, hampir semua siswa yang menjadi responden dalam penelitian ini adalah campers.

Campers adalah orang - orang yang berkemah. Mereka mengakhiri pendakiannya dan mencari tempat yang datar yang rata dan nyaman sebagai tempat bersembunyi dari situasi yag tidak bersahabat. Mereka memilih untuk menghabiskan sisa - sisa waktu demgan duduk disitu (Paul G.Stoltz: 2007: 19).

Siswa SMU Negeri 27 Jakarta Pusat sebenarnya memiliki potensi yang sangat besar untuk mendapatkan prestasi yang lebih baik lagi. Jika melihat hasil dari penelitian yang didapati bahwa sebagian besar siswa memiliki skor AQ dalam kategori sedang atau bertipe campers. Mengingat banyaknya permasalahan yang di hadapi oleh siswa dan beberapa faktor lain yang dapat mempengaruhi hasrat para siswa untuk berjuang demi pencapaian yang lebih baik lagi.

Pada dasarnya skor AQ bukanlah keadaan yang menetap melainkan masih dapat ditingkatkan dan diperbaiki. Siswa sebaiknya diajarkan untuk peka dengan masalah disekelilingnya, masalah dirinya, masalah teman - temannya karena dengan kemampuan itu, maka mereka akan dapat merasakan sebuah proses pendewasaan dirinya. Guru dan orangtua perlu menjadi pendengar yang baik karena dengan mendengar keluhan, harapan, dan kekhawatiran mereka dapat terjalin komunikasi yang baik. Dikelas guru dituntut untuk menjadikan proses belajar untuk menjadi media anak belajar mendengar, metode diskusi, curah pendapat, belajar untuk mengidentifikasikan masalah dan mencari berbagai alternatif solusinya.

\section{Kesimpulan}

Berdasarkan hasil pengumpulan data, perhitungan data dan pengolahan data statistik, maka dapat disimpulkan bahwa sebagian besar siswa SMU Negeri 27 Jakarta Pusat memiliki skor AQ berada dalam kategori sedang atau bertipe campers, yaitu pekemah, orang yang mendaki tetapi tidak mencapai puncak karena sudah merasa puas dengan apa yang dicapai. Tipe ini cenderung mencari aman dengan tinggal ditempat yang menurut mereka nyaman dan sedikit dapat menerima perubahan yang terjadi dalam hidupnya.

\section{Daftar Pustaka}

Arikunto, Suharsimi. (2008). Proses Penelitian Suatu Pendekatan Praktik. Jakarta: PT. Rhineka
Cipta.

Data TU SMU Negeri 27 Jakarta Pusat. Daftar Siswa kelas XI Tahun Ajaran 2010-2011.

Hamdani, \& Adz Dzakiey Barkan. (2005). Prophertic Intelegence (Menumbuhkan Potensi Hakiki Melalui Pengembangan dan Kesehatan Ruhani).

Irwanto. (1997). Psikologi Umum. Jakarta : PT. Gramedia Pustaka Utama.

Kuncono. (2004). Aplikasi Komputer Psikologi : Diktat Kuliah dan Panduan Praktikum. Jakarta : Fakultas Psikologi, Universitas Persada Indonesia.

Mahshasti. ( 2011). Gambaran Adversity Qoutient pada siswa di SMK Budi Asih , Jakarta. Universitas Negeri Jakarta : Jurusan Psikologi Pendididkan.

Masyhuri \& Zainudin. (2008). Metedologi Penelitian Pendekatan Praktis dan Aplikatif, Bandung : Refika Aditama.

Rangkuti, AA,\& Suryaratri, RD. (2009). Statistika Inferensial untuk Penelitian Psikologi Pendidikan. Jakarta : Fakultas Ilmu

Roosseno \& Wangsadinata Wiratman \& Suprayitno. (2008). Jembatan dan Menjembatani. Jakarta: Yayasan Obor Indonesia.

Shadily,H \& Echols, JM. (1998). Kamus Inggris Indonesia. Jakarta : PT Gramedia Pustaka Utama.

Stoltz, Paul G.( 2007). Adversity Quotient Mengubah Hambatan Menjadi Peluang. Jakarta.Grasindo.

Sugiyono. (2005). Statistika Untuk penelitian. Bandung. PT. ALFABETA.

Suryadibrata Sumadi. (2005). Pengembangan Alat Ukur Psikologis. .Yogyakarta : CV. Andi Offset.

Sutarjo. (2004). Pengantar Psiklogi Klinis.

Tim Penyusun Kamus Pusat (2007). Kamus Besar Bahasa Indonesia. Jakarta: Balai Pustaka.

Morgan ( $10 \quad$ Mei $2011 \quad$ ) http://www.zaldym.wordpres.com/2010/04/19/peng aruh-belajar-siswa-sebuah-studikepustakaan/diakses.

Ghandi Wirawan ( 10 Mei $2011 \quad$ ) http://www.majalahpendidikan.com/2011/05/presta si-belajar-siswa.html/ 